University of Nebraska - Lincoln

DigitalCommons@University of Nebraska - Lincoln

Agronomy \& Horticulture - Faculty Publications

Agronomy and Horticulture Department

2008

\title{
Cloning and characterization of a caesalpinoid (Chamaecrista fasciculata) hemoglobin: The structural transition from a nonsymbiotic hemoglobin to a leghemoglobin
}

\author{
Sabarinathan K. Gopalasubramaniam \\ Laboratorio de Biofísica y Biología Molecular, Facultad de Ciencias, Universidad Autónoma del Estado de \\ Morelos, Morelos, México \\ Frank A. Kovacs \\ University of Nebraska at Kearney, kovacsfa@unk.edu \\ Fernando Violante-Mota \\ Laboratorio de Biofísica y Biología Molecular, Facultad de Ciencias, Universidad Autónoma del Estado de \\ Morelos, Morelos, México \\ Paul Twigg \\ University of Nebraska at Kearney, twiggp@unk.edu \\ Raul Arredondo-Peter \\ Laboratorio de Biofísica y Biología Molecular, Facultad de Ciencias, Universidad Autónoma del Estado de \\ Morelos, Morelos, México \\ Sellowext thisand fadditionahworks at: https://digitalcommons.unl.edu/agronomyfacpub \\ Part of the Plant Sciences Commons
}

Gopalasubramaniam, Sabarinathan K.; Kovacs, Frank A.; Violante-Mota, Fernando; Twigg, Paul; ArredondoPeter, Raul; and Sarath, Gautam, "Cloning and characterization of a caesalpinoid (Chamaecrista fasciculata) hemoglobin: The structural transition from a nonsymbiotic hemoglobin to a leghemoglobin" (2008). Agronomy \& Horticulture -- Faculty Publications. 138.

https://digitalcommons.unl.edu/agronomyfacpub/138

This Article is brought to you for free and open access by the Agronomy and Horticulture Department at DigitalCommons@University of Nebraska - Lincoln. It has been accepted for inclusion in Agronomy \& Horticulture -Faculty Publications by an authorized administrator of DigitalCommons@University of Nebraska - Lincoln. 


\section{Authors}

Sabarinathan K. Gopalasubramaniam, Frank A. Kovacs, Fernando Violante-Mota, Paul Twigg, Raul Arredondo-Peter, and Gautam Sarath 


\title{
Cloning and characterization of a caesalpinoid (Chamaecrista fasciculata) hemoglobin: The structural transition from a nonsymbiotic hemoglobin to a leghemoglobin
}

\author{
Sabarinathan K. Gopalasubramaniam, ${ }^{1}$ Frank Kovacs, ${ }^{2}$ Fernando Violante-Mota, ${ }^{1}$ \\ Paul Twigg, ${ }^{3}$ Raúl Arredondo-Peter, ${ }^{1 \star}$ and Gautam Sarath ${ }^{4,5}$ \\ ${ }^{1}$ Laboratorio de Biofísica y Biología Molecular, Facultad de Ciencias, Universidad Autónoma del Estado de Morelos, \\ Morelos, México \\ 2 Department of Chemistry, University of Nebraska-Kearney, Kearney, Nebraska 66849 \\ ${ }^{3}$ Department of Biology, University of Nebraska-Kearney, Kearney, Nebraska 66849 \\ ${ }^{4}$ Grain, Forage and Bioenergy Research Unit, USDA-ARS, University of Nebraska-Lincoln, Lincoln, Nebraska 68588-0937 \\ ${ }^{5}$ Department of Agronomy and Horticulture, University of Nebraska-Lincoln, Lincoln, Nebraska 68588-0937
}

\section{ABSTRACT}

Nonsymbiotic hemoglobins (nsHbs) and leghemoglobins (Lbs) are plant proteins that can reversibly bind $\mathrm{O}_{2}$ and other ligands. The nsHbs are hexacoordinate and appear to modulate cellular concentrations of NO and maintain energy levels under hypoxic conditions. The Lbs are pentacoordinate and facilitate the diffusion of $\mathrm{O}_{2}$ to symbiotic bacteroids within legume root nodules. Multiple lines of evidence suggest that all plant Hbs evolved from a common ancestor and that Lbs originated from nsHbs. However, little is known about the structural intermediates that occurred during the evolution of pentacoordinate Lbs from hexacoordinate nsHbs. We have cloned and characterized a $\mathrm{Hb}$ $(p p H b)$ from the root nodules of the ancient caesalpinoid legume Chamaecrista fasciculata. Protein sequence, modeling data, and spectral analysis indicated that the properties of $\mathrm{ppHb}$ are intermediate between that of $n s \mathrm{Hb}$ and $\mathrm{Lb}$, suggesting that $\mathrm{ppHb}$ resembles a putative ancestral $\mathrm{Lb}$. Predicted structural changes that appear to have occurred during the $\mathrm{nsHb}$ to $\mathrm{Lb}$ transition were a compaction of the CDloop and decreased mobility of the distal His inhibiting its ability to coordinate directly with the heme-Fe, leading to a pentacoordinate protein. Other predicted changes include shortening of the $\mathrm{N}$ - and C-termini, compaction of the protein into a globular structure, disappearance of positive charges outside the heme pocket and appearance of negative charges in an area located between the $N$ - and C-termini. A major consequence for some of these changes appears to be the decrease in $\mathrm{O}_{2}$-affinity of ancestral $\mathrm{nsHb}$, which resulted in the origin of the symbiotic function of Lbs.

Proteins 2008; 72:252-260.

(C) 2008 Wiley-Liss, Inc.

Key words: Caesalpinoideae; evolution; function; globin; Leguminosae; modeling; origin; spectroscopy; structure; symbiosis.

\section{INTRODUCTION}

Nonsymbiotic and symbiotic hemoglobins (Hbs) are $\mathrm{O}_{2-}$ binding proteins that have been identified in plants. Symbiotic Hbs (or leghemoglobins (Lbs) when isolated from legumes) are specifically synthesized in the nodules of $\mathrm{N}_{2^{-}}$ fixing plants. A major function for Lbs is to facilitate the diffusion of $\mathrm{O}_{2}$ to the actively respiring bacteroids during $\mathrm{N}_{2}$-fixation. ${ }^{1,2}$ Nonsymbiotic Hbs (nsHbs) are synthesized in diverse organs from plants growing in normal and stressed conditions (reviewed in Ross et al. ${ }^{3}$ ).

Nonsymbiotic Hbs are classified into class- 1 and class-2 (nsHb-1 and nsHb-2, respectively). ${ }^{4}$ The $\mathrm{O}_{2}$-affinitiy of nsHb-1 and nsHb-2 is very high and high, respectively. ${ }^{4-6}$ The very high $\mathrm{O}_{2}$-affinity of nsHb-1 results from an extremely low $\mathrm{O}_{2}$-dissociation rate constant, thus it has been proposed that major functions for nsHbs-1 in plant cells are other than $\mathrm{O}_{2}$-transport, such as to modulate the levels of NO and maintain the energy status and redox potential. ${ }^{7-10}$ In contrast, the $\mathrm{O}_{2}$-dissociation rate constant for nsHbs-2 is higher than that of nsHbs-1, thus a likely function for nsHbs-2 is $\mathrm{O}_{2}$-transport. ${ }^{4,7}$

For many years $\mathrm{Hbs}$ were only identified in $\mathrm{N}_{2}$-fixing plants; however, during the last few decades Hbs have been detected in numerous (non- $\mathrm{N}_{2}$-fixing) land plants, ranging

Grant sponsor: Consejo Nacional de Ciencia y Tecnología (CoNaCyT); Grant number: 42873Q; Grant sponsor: PROMEP; Grant number: UAEMor-PCT-01-01/PTC23.

${ }^{*}$ Correspondence to: Raúl Arredondo-Peter, Lab. de Biofísica y Biología Molecular, Facultad de Ciencias, Universidad Autónoma del Estado de Morelos, Av. Universidad 1001, Col. Chamilpa, 62210 Cuernavaca, Morelos, México.

E-mail: normanac@terra.com.mx.

Received 28 September 2007; Revised 8 November 2007; Accepted 15 November 2007

Published online 23 January 2008 in Wiley InterScience (www.interscience.wiley. com). DOI: $10.1002 /$ prot. 21917 
from primitive bryophytes to evolved monocots and dicots (reviewed in Garrocho-Villegas et al. ${ }^{11}$ ), indicating their widespread occurrence in land plants. Also, sequence comparison showed that the $h b$ gene structure is identical in primitive and evolved nsHbs and Lbs, that is, $n s h b$ and $l b$ genes are interrupted by three introns located at identical positions. This evidence suggests that nsHbs and Lbs evolved from a common ancestor. ${ }^{1,12}$

The detection of nsHb with both symbiotic and nonsymbiotic specificities in $\mathrm{N}_{2}$-fixing plants suggests that symbiotic Hbs and Lbs originated from nshb genes. ${ }^{13-17}$ Although it is not yet certain that $\mathrm{Hb}$ is essential for $\mathrm{N}_{2^{-}}$ fixation in nonlegume plants, such as in Parasponia andersonii and actinorhizal plants, $\mathrm{Lb}$ is essential for $\mathrm{N}_{2^{-}}$ fixation in nodulating legumes. ${ }^{18}$ Thus, a specialization from nsHb to Lb apparently occurred during the evolution of $\mathrm{N}_{2}$-fixing legumes. Hoy et al. ${ }^{19}$ analyzed the crystal structure of barley and rice nsHb-1 and soybean Lba and proposed that functional $\left(\mathrm{O}_{2}\right.$-transporting $)$ Lbs originated after the stabilization of an open pentacoordinate conformation of nsHbs. However, the structural changes that occurred during the $\mathrm{nsHb}$ to $\mathrm{Lb}$ transition are largely not known. Also, nsHbs or Lbs that resemble a putative ancestor of Lbs have not yet been identified. This information is of interest to complement our understanding about the evolution of plant Hbs.

The Caesalpinoideae is the oldest subfamily in the Leguminosae family 20,21 and contains non-nodulating and nodulating species. 22,23 Thus, the evolution of a $\mathrm{nsHb}$ into a functional Lb probably occurred in a caesalpinoid legume. Here we report the characterization of a $\mathrm{Hb}$ (ppHb) from the nodulating caesalpinoid Chamaecrista fasciculata (Partridge pea), and describe a number of structural changes that probably occurred during the evolution of its symbiotic function.

\section{METHODS}

\section{Plant growth and root nodules harvest}

Seeds of Partridge pea (Chamaecrista fasciculata (Michx). Green) were obtained from plants grown in a field near Mead, NE. Seeds were scarified by gentle tumbling with coarse sand for $5 \mathrm{~min}$. Scarified seeds were mixed with a rhizobial commercial inoculum (Cowpea type, Bradyrhizobium sp. (Vigna), Royal Peat, Becker Underwood, Ames, IA) and planted in 10 inch clay pots in sterilized sand and raised in a greenhouse under natural light with $\sim 32^{\circ} \mathrm{C}$ day and $\sim 28^{\circ} \mathrm{C}$ night. After germination, plants were thinned to three seedlings/pot and watered twice weekly with a $\mathrm{N}_{2}$-free nutrient solution. 24 Plants were otherwise watered with distilled water as needed. Root nodules were harvested from both young and mature $(<2$ and $>5$ week old plants, respectively) plants, frozen in liquid $\mathrm{N}_{2}$, and stored at $-80^{\circ} \mathrm{C}$ until used.

\section{Table I}

Sequence Similarity and Identity Between $\mathrm{ppHb}$ and Selected nsHbs and Lbs

\begin{tabular}{l} 
Plant Hb \\
\hline Nonsymbiotic Hbs \\
Soybean nsHb1 \\
Parasponia andersonii nsHb1 \\
Trema orientalis nsHb1 \\
Tomato nsHb1 \\
Barley nsHb1 \\
Rice nsHb1 \\
Ceratodon purpureus $\mathrm{nsHb}$ \\
Physcomitrella patens $\mathrm{nsHb}$ \\
Cotton nsHb2 \\
Tomato nsHb2 \\
Arabidopsis nsHb2 \\
Symbiotic Hbs \\
Sesbania rostrata Lb \\
Soybean Lba \\
Cowpea Lbll \\
Yellow Lupin Lb
\end{tabular}

Similarity $(\%)$

Identity (\%)

Sequences of plant Hbs were obtained from the GenBank database (with the accession numbers reported by Garrocho-Villegas et al. ${ }^{11}$ ) and aligned by pairwise with $\mathrm{ppHb}$ using the BLAST program. Similarity values show amino acid position with identical polarity (negative, positive, or nonpolar) in aligned sequences. Identity values show identical amino acids in aligned sequences.

\section{cDNA library construction}

Library construction was essentially according to Tobias et al. ${ }^{25}$ Briefly, total RNA was extracted from frozen root nodules using the Concert Plant RNA reagent (Invitrogen). Messenger RNA was purified using the FastTrack 2.0 mRNA isolation system (Invitrogen). First strand cDNA synthesis was primed with a NotI-oligo(dT) adapter primer followed by second strand synthesis using the Superscript Plasmid System (Invitrogen). The resulting cDNAs were ligated to Sall adapters, digested with NotI and directionally cloned into the pSPORT1 cloning vector (Invitrogen). Plasmids containing cDNA inserts were transformed into Ultramax DH5 $\alpha \mathrm{FT}$ chemically competent Escherichia coli (Invitrogen). One hundred individual clones were randomly isolated and insert DNA was partially sequenced at the University of NebraskaLincoln Genomics Core Facility. A total of five clones containing cDNA sharing homology to known plant Hbs were selected and fully sequenced in both directions to assemble the full length cDNA and deduce the amino acid sequence of the Partridge pea $\mathrm{Hb}$ (ppHb).

\section{Sequence analysis and prediction of the ppHb structure}

Multiple sequence alignment and cluster analysis of $\mathrm{ppHb}$ and selected plant Hbs were performed by using the Neighbor Joining Method of the Clustal X program. 26 Sequence alignment was manually verified. Sequence similarity and identity values between $\mathrm{ppHb}$ and individual plant Hbs were obtained from pairwise 
стTTTCTTTATACAAAAgGCCTAAGCTTATTCAAGAAGATGgGTTTTAgC 50

$\begin{array}{lllll}M & G & F & S & 3\end{array}$

GAACAGCAAGAAGCCTTAGTTGTGAAGTCATGGAGCGTTCTCAAGAGCAA 100 $\begin{array}{llllllllllllllllll}E & \& & Q & E & A & \text { L } & \text { V } & \text { V } & \text { K } & \text { S } & \text { W } & \text { S } & \text { V } & \text { L } & K & \text { S } & \text { N } & 20\end{array}$

TTCTGAAGAGCTAGGTGCCAAGTTTTTCTTGAAGATATTTCAGCTTGCCC 150 $\begin{array}{lllllllllllllllllllllll}S & E & E & L & G & A & K & F & F & L & K & I & F & Q & L & A & 36\end{array}$

CAGCAGCCCAGAATTTGTTCTCTTTCATCAAAGATTCAAACGTCCCAGTG 200

$\begin{array}{llllllllllllllllllllllllllll}\mathrm{P} & \mathrm{A} & \mathrm{A} & \mathrm{Q} & \mathrm{N} & \mathrm{L} & \mathrm{F} & \mathrm{S} & \mathrm{F} & \mathrm{I} & \mathrm{K} & \mathrm{D} & \mathrm{S} & \mathrm{N} & \mathrm{V} & \mathrm{P} & \mathrm{V} & 53\end{array}$

GAACAAAACCCAAAACTCAÄGCCCCATGCTGCGGCTGTCTTTGTTCTGAT 250 $\begin{array}{llllllllllllllllll}\mathrm{E} & \mathrm{Q} & \mathrm{N} & \mathrm{P} & \mathrm{K} & \mathrm{L} & \mathrm{K} & \mathrm{P} & \mathrm{H} & \mathrm{A} & \mathrm{A} & \mathrm{A} & \mathrm{V} & \mathrm{F} & \mathrm{V} & \mathrm{L} & \mathrm{I} & 70\end{array}$

AGGTGAATCAGCAACTCAACTGGGGAAGGCTGGCAAGGTCACAGTGGATG 300 $\begin{array}{llllllllllllllllll}G & E & S & A & T & \& & L & G & K & A & G & K & V & T & V & D & 86\end{array}$

AAGCAATCTTGAAAAAAATAGGTGCTACCCATGCCAAAAGCGGAGTGCAA 350

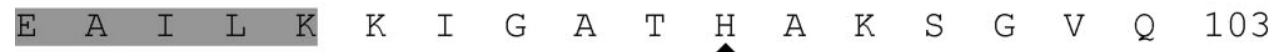

AATGAGCATtTTCCGGTGGCAAAATCTGCAтtTtTtGAAACCATAAAAGA 400 $\begin{array}{llllllllllllllllll}\mathrm{N} & \mathrm{E} & \mathrm{H} & \mathrm{F} & \mathrm{P} & \mathrm{V} & \mathrm{A} & \mathrm{K} & \mathrm{S} & \mathrm{A} & \mathrm{F} & \mathrm{F} & \mathrm{E} & \mathrm{T} & \mathrm{I} & \mathrm{K} & \mathrm{E} & 120\end{array}$ GGCAGCACCAGAACTGTGGTCAGCAGAGTTGGAGAGTGCATGGGGAGAAG 450 $\begin{array}{lllllllllllllllll}\text { A } & A & P & E & L & W & S & A & E & L & E & S & A & W & G & E & 136\end{array}$ СTTTTGACCAGCTAGCAGCTGCCATtAAAGCCCATACTTAATCTTCTCTA 500 $\begin{array}{lllllllllllllll}\text { A } & F & D & \& & L & A & A & A & I & K & A & H & \text { T } & * & 149\end{array}$ TAAGTATAGTCCTTTCCTCCTGAGTTCAAAATGGAGGATATATATACCAA 550 GTGATATCTTAATAATAATAAAAAAAAAGTGTGTTAATTTATATGAAATC 600 TGAGCTAGCCTATGTGATTAAGTTTGTGAGCTAGCCTATGAGGTTAAGTG 650

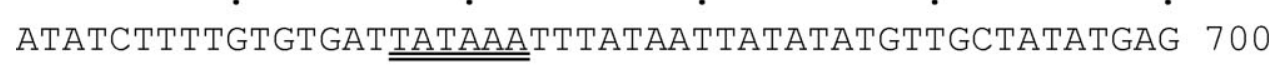
AAgAgtAATTCCGACTTTCAAgGTCGgGAAAgGATATGTATTACTTGAAG 750

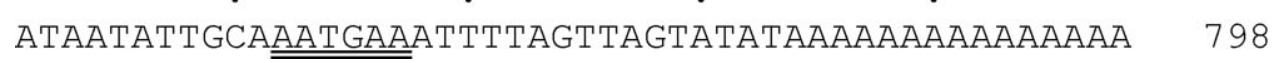

Figure 1

Nucleotide and deduced protein sequences of cDNA clone 11 that codes for C. fasciculata $H b(p p H b)$. Arrows show distal and proximal His at positions 62 and 97 , respectively. Putative polyadenylation signals are double-underlined. Peptides arising from native $\mathrm{ppHb}$ and identified by mass spectrometry are shaded in gray. The ppHb cDNA sequence is deposited in the GenBank database under the accession number EF534200. 


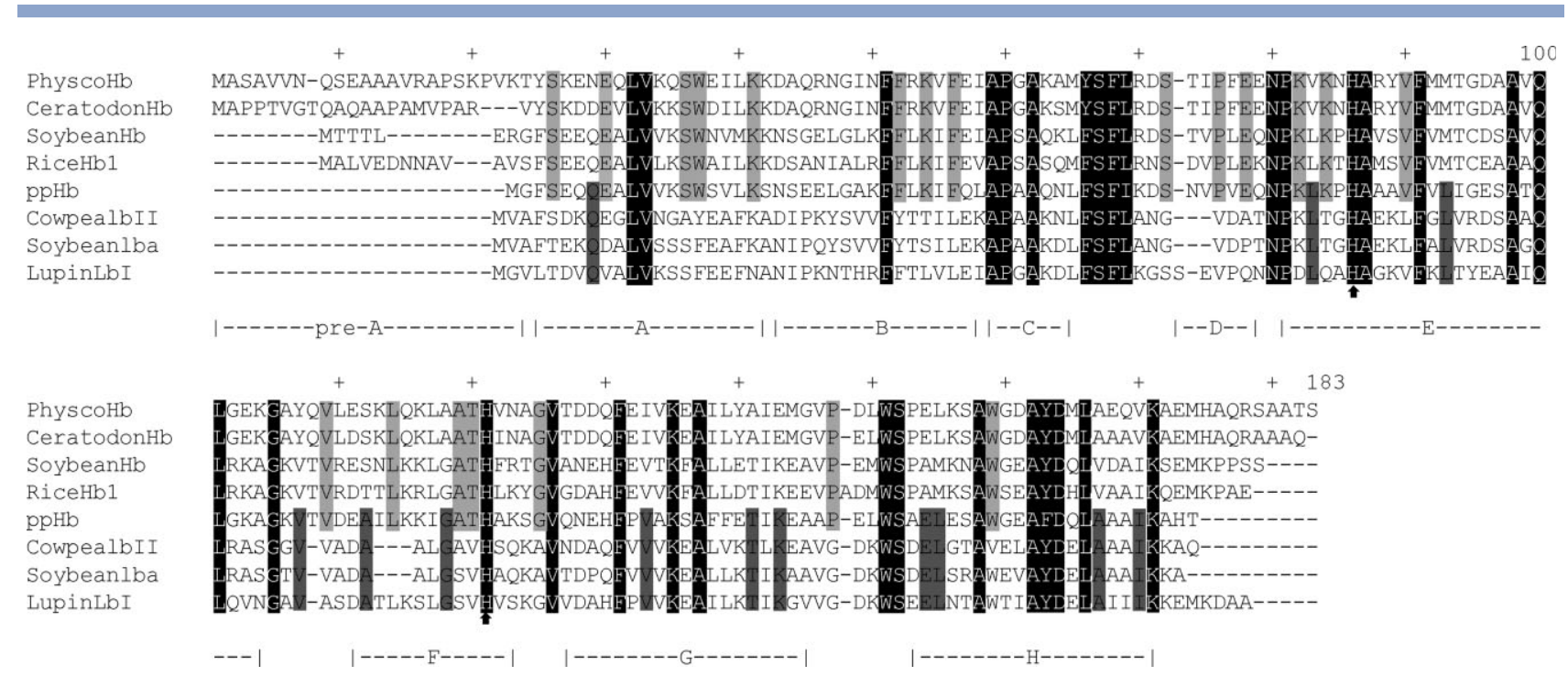

Figure 2

Sequence alignment of $\mathrm{ppHb}$ and selected plant nsHbs and Lbs. Arrows show distal and proximal His at positions 86 and 121 , respectively. Conserved amino acids in all aligned sequences are shown with black background. Amino acids conserved in aligned ppHb and nsHbs and Lbs are shown with light-and dark-gray background, respectively. Helices are shown with the A to H letters, and were designated (including to prehelix A) according to the position of helices in rice Hb1. 33 Sequences were obtained from the GenBank database using the following accession numbers: Physcomitrella (Physco) Hb: AF218049; Ceratodon Hb: AF309562; soybean Hb: U47143; rice Hb1: U76029; cowpea LbII: U33207; soybean Lba: V00453; lupin LbI: Y00401.

sequence alignments using the BLAST program 27 from the GenBank database (http://www.ncbi.nlm.nih.gov). The tertiary structure of $\mathrm{ppHb}$ was predicted by homology modeling 28 using the crystal structure of rice (nonsymbiotic) $\mathrm{Hb} 1$ (PDB ID 1D8U) as template. The ppHb and rice $\mathrm{Hbl}$ amino acid sequences (GenBank accession numbers EF534200 and U76030, respectively) were aligned using the Homology module of the Insight II program (Accelrys), and amino acids were automatically substituted. The best rotamer for all side chains was searched automatically using the default parameters of the Homology module. The energy of the whole structure was minimized (100 steps of the steepest descent minimization) using the Discovery force field from Insight II, and the best rotamers for all amino acid side chains were searched again. The refined ppHb model was analyzed using routines available from the SwissPDBViewer program (http://ca.expasy.org/spdbv/) (below). Images were edited using the VMD program. 29

\section{Expression and purification of recombinant ppHb}

A cDNA coding for $\mathrm{ppHb}$ was subcloned into the expression vector pET28a (Novagen) and transformed into E. coli following the manufacturer's instructions. Recombinant $\mathrm{ppHb}$ was purified to homogeneity by Nickel-interaction chromatography, followed by ionexchange chromatography. Protein purification was verified by SDS-PAGE. ${ }^{30}$ Total protein was quantitated by using a dye-binding assay (Bio-Rad) and bovine serum albumin as standard, and the recombinant $\mathrm{ppHb}$ was quantified on the heme basis using the dipyridine-hemochrome assay. 31

\section{Spectroscopic analysis of recombinant ppHb}

Purified recombinant $\mathrm{ppHb}$ was characterized spectrophotometrically using a GBC UV/Vis911A spectrophotometer interfaced to a computer. Ferrous $\mathrm{ppHb}$ was oxidized to ferric $\mathrm{ppHb}$ by the addition of potassium ferricyanide (final concentration of $200 \mu \mathrm{M}$ ) in $50 \mathrm{mM}$ sodium phosphate buffer ( $\mathrm{pH} \mathrm{6)}$, and then chromatographed on a PD-10 column (Amersham-Pharmacia) equilibrated with $50 \mathrm{mM}$ phosphate buffer at $\mathrm{pH}$ 7. Ferrous $\mathrm{ppHb}$ was formed by the addition of few crystals of sodium dithionite (Fluka). Air was bubbled through the ppHb solution to generate the $\mathrm{O}_{2}$-ligated form of $\mathrm{ppHb}$.

\section{RESULTS AND DISCUSSION}

\section{Cloning of a cDNA coding for a caesalpinoid (C. fasciculata) Hb}

With the exception of a partial characterization of a mimosoid Lb, ${ }^{32}$ no work has been done on Lbs other than papilionoid Lbs. Little is known about the properties of Hbs/Lbs from caesalpinoid and mimosoid species, which are ancestral legumes. The analysis of caesalpinoid $\mathrm{Hbs} / \mathrm{Lbs}$ is of interest because the Caesalpinoideae is the 


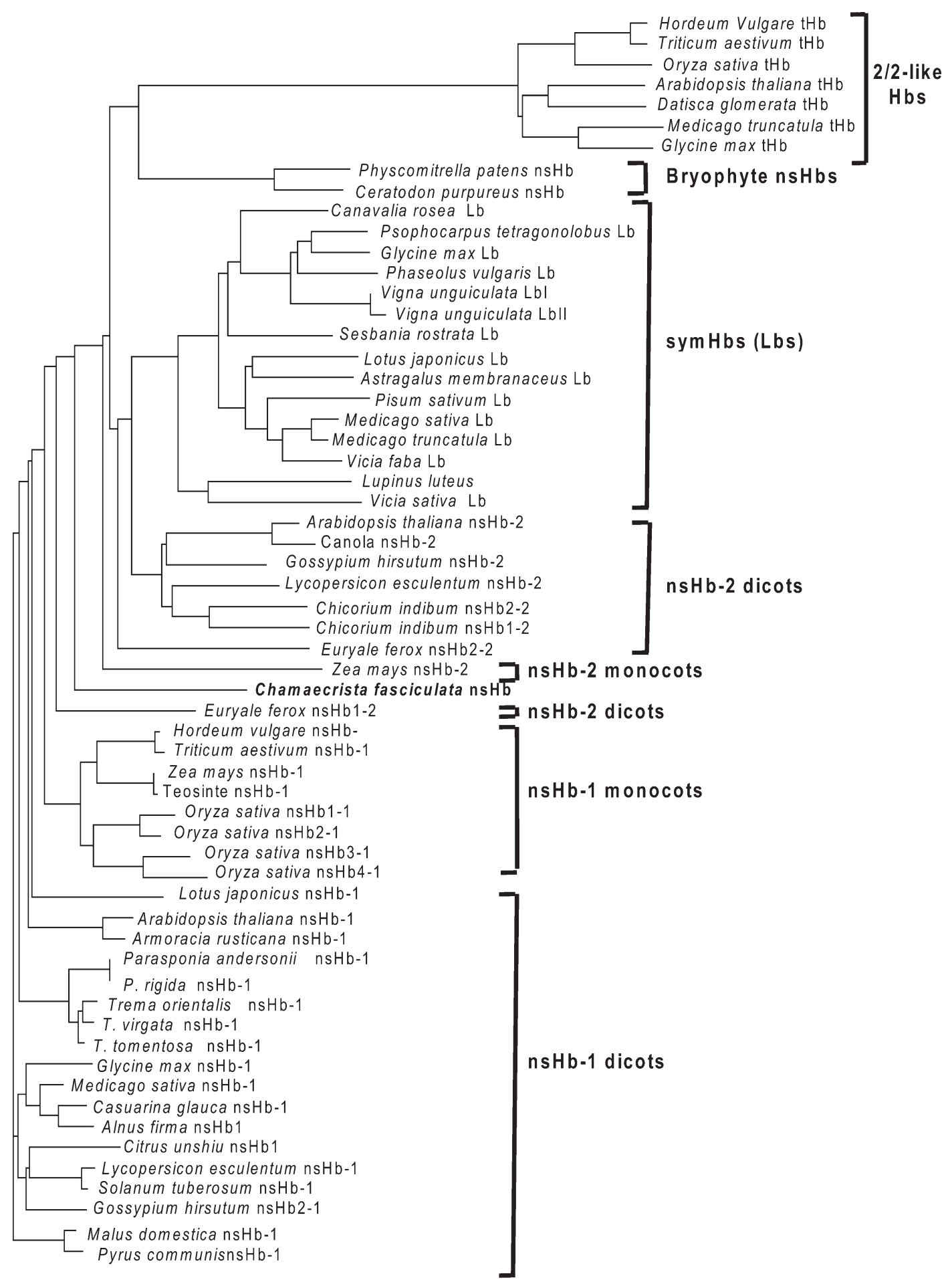

\section{Figure 3}

Phenetic relationships between $\mathrm{ppHb}$ and selected plant (nonsymbiotic and symbiotic) Hbs. The phenogram was constructed from sequences reported by Garrocho-Villegas et al. ${ }^{11}$

oldest subfamily of the Leguminosae family, 20,21 thus it is probable that a functional $\left(\mathrm{O}_{2}\right.$-transporting $)$ Lb originated within a caesalpinoid legume. We isolated one clone (clone 11) from a cDNA library constructed from the caesalpinoid Chamaecrista fasciculata (Partridge pea) root nodules. Partial sequencing of $100 \mathrm{cDNA}$ clones 
showed that clone 11 is highly abundant (it represents $14 \%$ of the sequenced clones), and full sequencing and sequence comparison with sequences deposited in the GenBank database showed that clone 11 is similar to plant $\mathrm{Hb}$ sequences (Table I). Predicted protein sequence from clone 11 contains the highly conserved amino acid residues of plant and nonplant $\mathrm{Hbs}$ (below). Thus, clone 11 codes for a plant (caesalpinoid) $\mathrm{Hb}$ and was named as (Partridge pea) ppHb. The ppHb cDNA clone is $798 \mathrm{bp}$ in length, contains 38 and $407 \mathrm{bp}$ at the $5^{\prime}$-(upstream) and $3^{\prime}$-(downstream) noncoding regions, respectively, and putative polyadenylation signals located at positions 567,667 , and 762, and codes for a predicted polypeptide 149 amino acids in length (see Fig. 1) with a calculated molecular weight of 16,196 Da. Predicted ppHb contains the highly conserved distal and proximal His at positions 62 and 97, respectively.

Because of the high abundance of ppHb cDNA (above) we concluded that $\mathrm{ppHb}$ is the major $\mathrm{Hb}$ in the $C$. fasciculata root nodules. This was verified by isolating and de novo sequencing of the major $C$. fasciculata nodule $\mathrm{Hb}$ by gel electrophoresis followed by mass spectrometry. The sequences obtained for several peptides were identical to that of the predicted $\mathrm{ppHb}$ protein (highlighted on the amino acid sequence shown in Fig. 1).

\section{Phenetic relationship of ppHb with Plant Hbs}

Sequence comparison of the $\mathrm{ppHb}$ protein with sequences deposited in databases showed that the $\mathrm{ppHb}$ similarity and identity values are higher to plant nsHbs than to Lbs (Table I). This observation showed that $\mathrm{ppHb}$ is a nonsymbiotic or nonsymbiotic-like $\mathrm{Hb}$ rather than a Lb. Thus, because transcripts coding for $\mathrm{ppHb}$ were abundant in the screened library and $\mathrm{ppHb}$ is the major nodule $\mathrm{Hb}$ (above), it is likely that nonsymbiotic (-like) ppHb, but not $\mathrm{Lb}$, is the functional $\mathrm{Hb}$ in the C. fasciculata root nodules. Sequence alignment of $\mathrm{ppHb}$ with selected plant nsHbs and Lbs showed that highly conserved amino acid residues in nsHbs and Lbs are also conserved in $\mathrm{ppHb}$, and that amino acids conserved in either nsHbs or Lbs are also conserved in $\mathrm{ppHb}$ (see Fig. 2). Phenetic analysis showed that $\mathrm{ppHb}$ clusters intermediate between nsHbs-1 and nsHbs-2 and Lbs (see Fig. 3). These observations show that $\mathrm{ppHb}$ is intermediate between nsHbs and Lbs, and suggest that it is an evolutionary transition from nsHbs to Lbs. Thus, to learn about the properties of ppHb, we performed structural analyses by predicting the structure of $\mathrm{ppHb}$ and obtaining the $\mathrm{UV} /$ visible spectra of a recombinant $\mathrm{ppHb}$.

\section{Characteristics of the predicted ppHb structure}

The tertiary structure of proteins can be predicted with high reliability using in silico methods and template structures (i.e., those experimentally elucidated by X-ray crystallography and/or NMR techniques) when the homology between two proteins is $\geq 30 \%$. 28,34-36 We predicted the tertiary structure of $\mathrm{ppHb}$ using rice (nonsymbiotic) $\mathrm{Hb} 1$ as a template since $\mathrm{ppHb}$ is more similar to nsHbs-1 $(\sim 60 \%-80 \%)$ than to Lbs $(\sim 60 \%)$ (Table I). However, to identify variations due to template homologs the structure of $\mathrm{ppHb}$ was also predicted using soybean
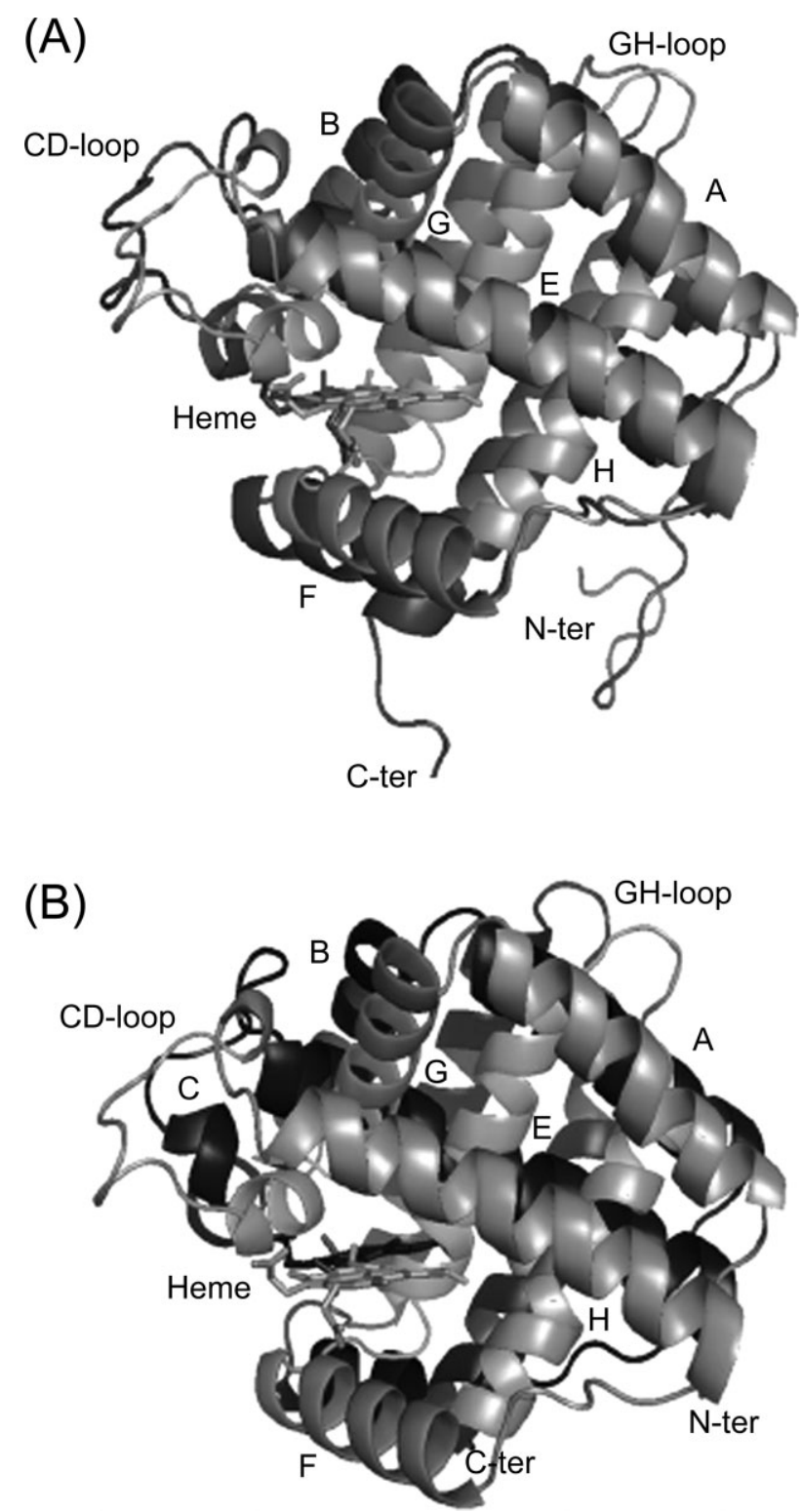

Figure 4

Overlay of the predicted structure of $\mathrm{ppHb}$ (gray) to the native structure of rice $\mathrm{Hbl}$ (A) and soybean Lba (B) (black). Helices are indicated with letters A-H. Coordinates for the rice $\mathrm{Hbl}$ and soybean $\mathrm{Lba}$ structures were obtained from the PDB database with the ID numbers $1 D 8 U$ and $1 B I N$, respectively. For experimental details see the Materials and Methods section. The predicted structure of $\mathrm{ppHb}$ is deposited in the Protein Model Database (http:// mi.caspur.it/PMDB/) under the ID number PM0075011. 


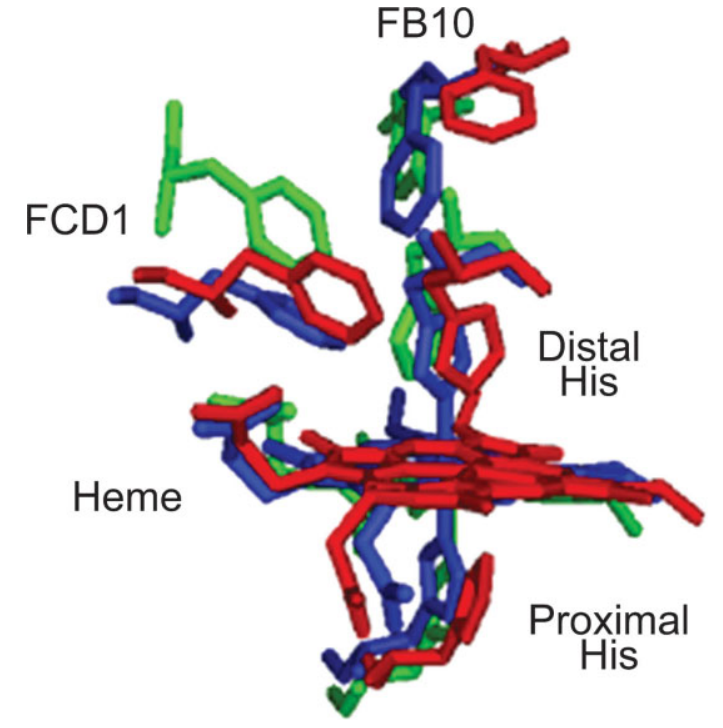

Figure $\mathbf{5}$

Comparison of the position and orientation of selected amino acids in the $\mathrm{ppHb}$ (red), rice Hbl(blue), and soybean Lba (green) heme pocket.

Lba (PDB ID 1BIN) as template. The resulting model of predicted $\mathrm{ppHb}$ was identical to that predicted from template rice $\mathrm{Hbl}$ (not shown), thus no variations were identified for the $\mathrm{ppHb}$ structure predicted from either rice $\mathrm{Hbl}$ or soybean Lba. Figure 4 shows that predicted $\mathrm{ppHb}$ folds into the globin fold and that its structure is more similar to the structure of rice Hb1 than to that of soybean Lba. With the exception of the N- and C-termini, the structure of predicted $\mathrm{ppHb}$ is quite similar to the structure of rice $\mathrm{Hb} 1$, including the positions of helices $\mathrm{E}$ and $\mathrm{F}$, where the distal and proximal $\mathrm{His}$ are located, respectively [Fig. 4(A)]. However, a number of differences were identified when the structures of predicted $\mathrm{ppHb}$ and soybean $\mathrm{Lb} a$ were compared [Fig. 4(B)]. Specifically, major differences between ppHb and soybean Lba exist at the CD-loop/helices B and C, $\mathrm{GH}-$ loop and position of the heme prosthetic group. A close examination of the amino acids that are essential for binding of ligands to the heme-Fe showed that in $\mathrm{ppHb}$ the position of distal His and Phe B10 and CD1 is intermediate between rice $\mathrm{Hbl}$ and soybean Lba (see Fig. 5). An interesting observation is that the distance of proximal His in predicted ppHb is $\sim 3.6 \AA$ farther from the heme-Fe than in rice $\mathrm{Hb} 1$ and soybean $\mathrm{Lb} a$.

\section{Spectroscopic properties of recombinant ppHb}

Spectral analysis showed that the absorption maxima of ferrous and ferric recombinant $\mathrm{ppHb}$ are located at
431 and $557 \mathrm{~nm}$ and 404, 542, and $633 \mathrm{~nm}$, respectively, similarly to those of soybean Lba. Also, the absorption maxima of ferrous oxygenated recombinant $\mathrm{ppHb}$ were located at 413,540, and $575 \mathrm{~nm}$, similarly to those of oxygenated soybean $\mathrm{Lb} a$ and rice $\mathrm{Hb} 1$ (Table II). This evidence indicates that recombinant $\mathrm{ppHb}$ is pentacoordinate and that it binds $\mathrm{O}_{2}$. Modeling analysis predicted that the position of distal $\mathrm{His}$ in $\mathrm{ppHb}$ is intermediate between rice $\mathrm{Hb} 1$ and soybean Lba (see Fig. 5); however, the spectral analysis showed that the recombinant $\mathrm{ppHb}$ is pentacoordinate (Table II). These observations indicate that $\mathrm{ppHb}$ is structuraly intermediate between nsHbs and Lbs and suggest that it probably binds $\mathrm{O}_{2}$ similarly to Lbs and thus functions as an $\mathrm{O}_{2}$-carrier into the C. fasciculata root nodules.

\section{Conclusions}

A prerequisite to the origin of an efficient $\mathrm{N}_{2}$-fixing symbiosis between rhizobia and legume hosts was the existence of a Lb able to carry and deliver $\mathrm{O}_{2}$ to the respiring bacteroids. Nonsymbiotic Hbs are widespread in land plants and Lbs are restricted to legumes, ${ }^{11}$ thus Lbs originated from nsHbs. It has been postulated that Lbs evolved from either nsHb-1 15 or nsHb-2.4,12,19 The observation that $\mathrm{ppHb}$ sequence similarity is higher to nsHb-1 than to nsHb-2 $(77 \%-83 \%$ and $62 \%-68 \%$, respectively) (Table I) suggests that $\mathrm{ppHb}$ could have originated from a nsHb-1 and not from a nsHb-2. This observation also discards the possibility that $\mathrm{ppHb}$ is a nsHb-2 and not an evolutionary intermediate between nsHb-1 and Lb.

If $\mathrm{ppHb}$ and Lbs evolved from a nsHb-1, it is unlikely that the ancestral nsHb-1 functioned in $\mathrm{N}_{2}$-fixing nodules by delivering $\mathrm{O}_{2}$ to bacteroids because of its extremely low $\mathrm{O}_{2}$-dissociation rate constant. To function as an $\mathrm{O}_{2}$-carrier structural changes needed to have

\begin{tabular}{|c|c|c|c|c|c|}
\hline \multicolumn{6}{|c|}{$\begin{array}{l}\text { Table II } \\
\text { Spectral Characteristics of ppHb, Soybean } \mathrm{Lba}^{31} \text { and Rice } \mathrm{Hbl}^{6}\end{array}$} \\
\hline \multirow[b]{2}{*}{ State/ligand } & \multicolumn{5}{|c|}{ Absorption maxima (nm) } \\
\hline & Søret region & & & & \\
\hline \multicolumn{6}{|l|}{$\overline{p p H b}$} \\
\hline Ferric & 404 & & 542 & & 633 \\
\hline Ferrous deoxygenated & 431 & \multicolumn{3}{|c|}{557} & \\
\hline Ferrous oxygenated & 413 & & 540 & 575 & \\
\hline \multicolumn{6}{|l|}{ Soybean Lba } \\
\hline Ferric & 404 & & 534 & & 627 \\
\hline Ferrous deoxygenated & 427 & \multicolumn{3}{|c|}{557} & \\
\hline Ferrous oxygenated & 411 & & 541 & 575 & \\
\hline \multicolumn{6}{|l|}{ Rice $\mathrm{Hb1}$} \\
\hline Ferric & 410 & \multirow{2}{*}{\multicolumn{2}{|c|}{540}} & & \\
\hline Ferrous deoxygenated & 424 & & & & \\
\hline Ferrous oxygenated & 412 & & 540 & 576 & \\
\hline
\end{tabular}




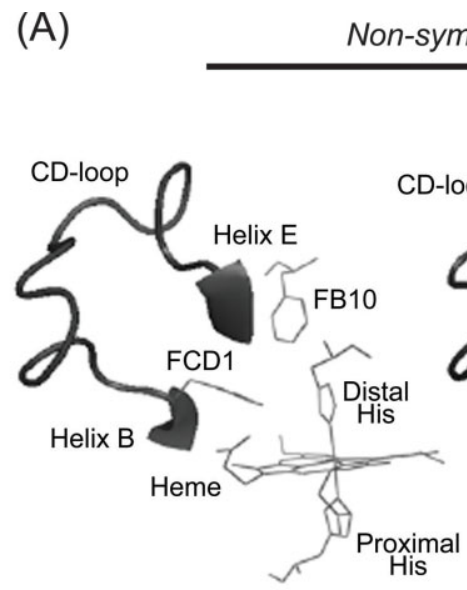

Rice Hb1

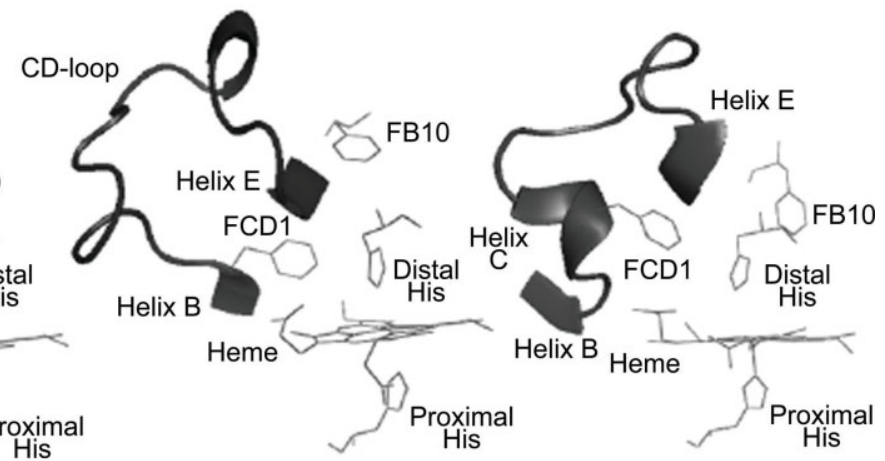

ppHb

\section{Soybean Lba}

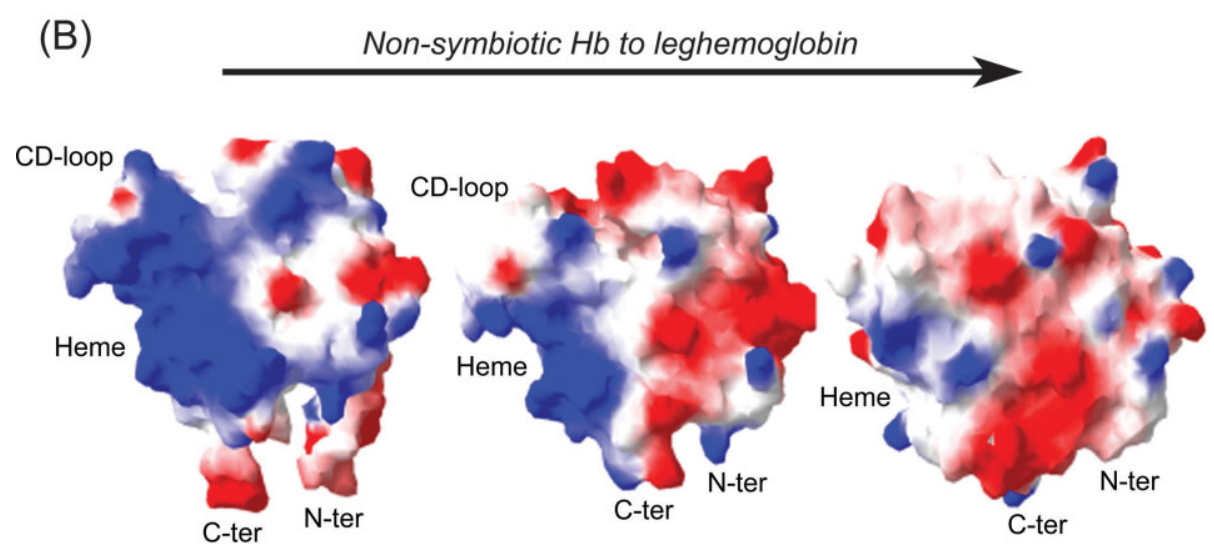

Rice Hb1

ppHb

Soybean Lba

\section{Figure 6}

Comparison of the rice $\mathrm{Hbl}, \mathrm{ppHb}$, and soybean Lba CD-loop regions (A) and surface charge distribution (B). The heme position in (B) is shown as an approximation. $B l u e$ and red colors in (B) represent positively and negatively charged amino acids, respectively. The arrows above the figures illustrate the postulated nsHb to Lb evolutionary transition.

occurred in the ancestral nsHb-1 to evolve into a functional Lb. The comparative structural analysis of nsHb-1 (rice $\mathrm{Hb} 1$ ) and $\mathrm{Lb}$ (soybean $\mathrm{Lb} a$ ) with $\mathrm{ppHb}$ permitted us to identify the major structural changes that probably occurred during the $\mathrm{nsHb}$ to $\mathrm{Lb}$ transition. These changes include the following: (i) a hexacoordinate to pentacoordinate transition and changes in the position of residues lining the heme-pocket (see Fig. 5) ${ }^{19}$; (ii) the size decrease and organization of the CD-loop [Fig. 6(A)], which limited the mobility of the helix E and positioned distal His away from the heme-Fe (i.e., in a pentacoordinate position) permiting more efficient $\mathrm{O}_{2-}$ transfer; (iii) the $\mathrm{N}$ - and $\mathrm{C}$-termini length decrease resulting in the disappearance of the N/C-pocket region 35 and compaction of the protein into a globular structure; and (iv) the disappearance of positive charges outside the heme pocket and appearance of negative charges in an area located between the $\mathrm{N}$ - and C-termini [Fig. 6(B)]. These structural changes probably had consequences in the $\mathrm{Hb}$ function into the plant cell, which resulted in the origin of the symbiotic function of Lbs.

\section{ACKNOWLEDGMENTS}

Mention of trade names or commercial products in this publication is solely for the purpose of providing specific information and does not imply recommendation or endorsement by the US Department of Agriculture. 


\section{REFERENCES}

1. Appleby CA. Leghemoglobin and Rhizobium respiration. Annu Rev Plant Physiol 1984;35:443-478.

2. Appleby CA. The origin and functions of haemoglobin in plants. Sci Progress 1992;76:365-398.

3. Ross EJH, Lira-Ruan V, Arredondo-Peter R, Klucas RV, Sarath G. Recent insights into plant hemoglobins. Rev Plant Biochem Biotechnol 2002;1:173-189.

4. Trevaskis B, Watts RA, Andersson SR, Llewellyn DJ, Hargrove MS, Olson JS, Dennis ES, Peacock WJ. Two hemoglobin genes in Arabidopsis thaliana: the evolutionary origins of leghemoglobins. Proc Natl Acad Sci USA 1997;94:12230-12234.

5. Duff SMG, Wittenberg JB, Hill RD. Expression, purification and properties of recombinant barley (Hordeum sp.) hemoglobin: optical spectra and reactions with gaseous ligands. J Biol Chem 1997; 272:16746-16752.

6. Arredondo-Peter R, Hargrove MS, Sarath G, Moran JF, Lohrman J, Olson JS, Klucas RV. Rice hemoglobins: gene cloning, analysis and oxygen-binding kinetics of a recombinant protein synthesized in Escherichia coli. Plant Physiol 1997;115:1259-1266.

7. Arredondo-Peter R, Hargrove MS, Moran JF, Sarath G, Klucas RV. Plant hemoglobins. Plant Physiol 1998;118:1121-1126.

8. Sowa AW, Duff SMG, Guy PA, Hill RD. Altering hemoglobin levels changes energy status in maize cells under hypoxia. Proc Natl Acad Sci USA 1998;95:10317-10321.

9. Dordas C, Hasinoff BB, Igamberdiev AU, Manasc'h N, Rivoal J, Hill RD. Expression of a stress-induced hemoglobin affects NO levels produced by alfalfa root cultures under hypoxic stress. Plant J 2003;35:763-770.

10. Hebelstrup KH, Igamberdiev AU, Hill RD. Metabolic effects of hemoglobin gene expression in plants. Gene Funct Genom 2007; 398:86-93.

11. Garrocho-Villegas V, Gopalasubramaniam SK, Arredondo-Peter R. Plant hemoglobins: what we know six decades after their discovery. Gene Funct Genom 2007;398:78-85.

12. Hunt PW, Watts RA, Trevaskis B, Llewelyn DJ, Burnell J, Dennis ES, Peacock WJ. Expression and evolution of functionally distinct haemoglobin genes in plants. Plant Mol Biol 2001;47:677-692.

13. Appleby CA, Tjepkema JD, Trinick MJ. Hemoglobin in a nonleguminous plant Parasponia: possible genetic origin and function in nitrogen fixation. Science 1983;220:951-953.

14. Jacobsen-Lyon K, Jensen EO, Jorgensen J, Marcker KA, Peacock WJ, Dennis ES. Symbiotic and nonsymbiotic hemoglobin genes of Casuarina glauca. Plant Cell 1995;7:213-223.

15. Andersson CR, Jensen EO, Llewellyn DJ, Dennis ES, Peacock WJ. A new hemoglobin gene from soybean: a role for hemoglobin in all plants. Proc Natl Acad Sci USA 1996;93:5682-5687.

16. Heckmann AB, Hebelstrup KH, Larsen K, Micaelo NM, Jensen EO. A single hemoglobin gene in Myrica gale retains both symbiotic and non-symbiotic specificity. Plant Mol Biol 2006;61:769779 .

17. Sasakura F, Uchiumi T, Shimoda Y, Suzuki A, Takenouchi K, Higashi S, Abe M. A class 1 hemoglobin gene from Alnus firma functions in symbiotic and nonsymbiotic tissues to detoxify nitric oxide. Mol Plant Microbe Interact 2006;19:441-450.
18. Ott T, van Dongen JT, Günther C, Krusell L, Desbrosses G, Vigeolas H, Bock V, Czechowski T, Geigenberger P, Udvarvi MK. Symbiotic leghemoglobins are crucial for nitrogen fixation in legume root nodules but not for general plant growth and development. Curr Biol 2005; 15:531-535.

19. Hoy JA, Robinson H, Trent JT, III, Kakar S, Smagghe BJ, Hargrove MS. Plant hemoglobins: a molecular fossil record for the evolution of oxygen transport. J Mol Biol 2007;371:168-179.

20. Polhill RM, Raven PH. Advances in legume systematics. London: Royal Botanic Gargens, Kew; 1981. 1049 pp.

21. Bruneau A, Forest F, Herendeen PS, Klitgaard BB, Lewis GP. Phylogenetic relationships in the Caesalpinoideae (Leguminosae) as inferred from chloroplast trnL intron sequences. Syst Bot 2001;26: 487-514.

22. Corby HDL. The systematic value of leguminous root nodules. In: Polhill RM, Raven PH, editors.Advances in legume systematics, Vol. 2. London; Kew: Royal Botanic Gardens; 1981. pp 657-670.

23. Corby HDL. Types of rhizobial nodules and their distribution among the leguminosae. Kirkia 1988;13:53-123.

24. Sarath G, Pfieffer NE, Sodhi CS, Wagner FW. Bacteroids are stable during dark-induced senescence of soybean root nodules. Plant Physiol 1986;82:346-350.

25. Tobias CM, Twigg P, Hayden DM, Vogel KP, Mitchel RM, Lazo GR, Chow EK, Sarath G. Gene discovery and the identification of associated short tandem repeats in switchgrass a C4 perennial grass. Theor Appl Genet 2005;111:956-964.

26. Thompson JD, Gibson TJ, Plewniak F, Jeanmougin F, Higgins DG. The clustal $\mathrm{X}$ windows interface: flexible strategies for multiple sequence alignment aided by quality analysis tools. Nucleic Acids Res 1997;24:4876-4882.

27. Altschul SF, Gish W, Miller W, Myers EW, Lipman DJ. Basic local alignment search tool. J Mol Biol 1990;215:403-410.

28. Gopalasubramaniam SK, Garrocho-Villegas V, Bustos G, Pastor N, Arredondo-Peter R. Use of in silico (computer) methods to predict and analyze the tertiary structure of plant hemoglobins. Methods Enzymol 2008;436:389-406.

29. Humphrey W, Dalke A, Schulten K. VMD-Visual molecular dynamics. J Mol Graph 1996;14:33-38.

30. Laemmli UK. Cleavage of structural proteins during the assemble of the head of bacteriophage T4. Nature 1970;227:680-685.

31. Appleby CA, Bergersen FJ. Preparation and experimental use of leghemoglobin. In: Bergersen FJ, editor. Methods for evaluating biological nitrogen fixation. Chichester: Wiley; 1980. pp 315-335.

32. Lira-Ruan K, Sarath G, Klucas RV, Arredondo-Peter R. Characterization of leghemoglobin from a mimosoid legume. Leucaena esculenta, root nodules. Braz J Plant Physiol 2000;12:37-44.

33. Hargrove M, Brucker EA, Stec B, Sarath G, Arredondo-Peter R, Klucas RV, Olson JS, Philips GN, Jr. Crystal structure of a nonsymbiotic hemoglobin. Structure 2000;8:1005-1014.

34. Kretsinger RH, Ison RE, Hovmöller S. Prediction of protein structure. Methods Enzymol 2004;383:1-27.

35. Sáenz-Rivera J, Sarath G, Arredondo-Peter R. Modeling the tertiary structure of a maize (Zea mays ssp. mays) non-symbiotic hemoglobin. Plant Physiol Biochem 2004;42:891-897.

36. Petrey D, Honig B. Protein structure prediction: inroads to biology. Mol Cell 2005;20:811-819. 